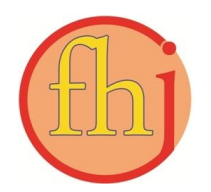

Faletehan Health Journal, 6 (3) (2019) 106-110

www. journal.Ippm-stikesfa.ac.id/ojs/index.php/FHJ

ISSN 2088-673X | e-ISSN 2597-8667

\title{
Penggunaan Billy Blanket Pada Neonatus Dalam Menurunkan Kadar Bilirubin
}

\author{
Grace Issabella Ambarita ${ }^{1}$, Lina Dewi Anggraeni ${ }^{1 *}$ \\ ${ }^{1}$ Sekolah Tinggi Ilmu Kesehatan (STIK) Sint Carolus, Jakarta, Indonesia \\ *Corresponding Author: linadewiam@gmail.com
}

\begin{abstract}
Abstrak
Hiperbilirubinemia adalah peningkatan kadar bilirubin dalam darah, secara klinis di tandai dengan ikterus. Kondisi hiperbilirubinemia yang berkepanjangan dapat mengakibatkan kernikterus yaitu keadaan kerusakan pada otak akibat perlengketan kadar bilirubin pada otak. Penelitian ini bertujuan untuk mengetahui gambaran penurunan kadar bilirubin dengan penggunaan Billy Blanket pada neonates di RS X Jakarta. Metode penelitian ini adalah metode penelitian kuantitatif dengan desain deskriptif analitik. Populasi penelitian ini berjumlah 60 responden. Teknik pengambilan sampel yang digunakan adalah total sampling. Data yang dikumpulkan merupakan data sekunder yang berkaitan dengan karakteristik dan kadar bilirubin neonatus yang diperoleh melalui catatan rekam medik. Analisis data dengan menggunakan analisis univariat untuk mengetahui gambaran distribusi frekuensi dari karakteristik dan penurunan kadar bilirubin neonatus yang mengunakan Billy Blanket. Responden sebagian besar berjenis kelamin laki-laki (51,7\%), responden dilahirkan pada usia kehamilan $\geq 37$ minggu sebanyak 73,3\%, responden berusia 2 hari sebanyak $40 \%$, dan seluruh responden memiliki $B B L 2500$ gram. Hasil penelitian menunjukkan bahwa kadar bilirubin setelah menggunakan Billy Blanket selama 24 jam dan 48 jam memiliki kadar bilirubin $>10 \mathrm{~g} / \mathrm{dl}$ sedangkan penggunaan Billy Blanket selama 72 jam menunjukkan 51,7\% memiliki kadar bilirubin 5-10 g/dl. Penggunaan Billy Blanket dapat dipertimbangkan menjadi salah satu intervensi keperawatan sehingga asuhan keperawatan lebih optimal.
\end{abstract}

Kata Kunci: Billy Blanket, Hiperbilirubinemia, Neonatus

\begin{abstract}
Hyperbilirubinemia is increased levels of bilirubin in the blood, which is on the mark with icteric. The condition can lead to prolonged hyperbilirubinemia kernicterus that is the state of the damage to the brain due to adhesions of bilirubin levels in the brain. This research aims to know the description of bilirubin levels decrease with the use of a Billy Blanket in neonates at $X$ hospital Jakarta. The research method used is descriptive analytic with quantitative design. This research population numbered 60 respondents. The sampling techniques used are the total sampling. The secondary data were obtained from patients' medical records and were analyzed through an analysis univariate to find out the frequency distribution of characteristics and decreased neonates bilirubin levels using Billy Blanket. Majority of respondents characteristic sex male were $51.7 \%$, respondents was born at $\geq 37$ weeks gestational age were $73.3 \%$, respondents aged 2 days were $40 \%$ and all of the respondents have $B B L 2500$ grams. The results showed that levels of bilirubin after using a Billy Blanket for 24 hours and 48 hours of $100 \%$ of the respondents have the levels of bilirubin $>10 \mathrm{~g} / \mathrm{dl}$ during the 72 hours while most respondents $51.7 \%$ had levels of bilirubin $5-10 \mathrm{~g} / \mathrm{dl}$. The use of a Billy Blanket may be considered to be one of the nursing interventions nursing care so that more optimal.
\end{abstract}

Keywords: Billy Blanket, Hyperbilirubinemia, Neonates 
Faletehan Health Journal, 6 (3) (2019) 106-110 www. journal.Ippm-stikesfa.ac.id/ojs/index.php/FHJ ISSN 2088-673X | e-ISSN 2597-8667

\section{Pendahuluan}

Hiperbilirubinemia adalah kadar bilirubin dalam darah meningkat, baik oleh faktor fisiologik maupun non fisiologik, secara klinis ditandai dengan ikterus. Ikterus terjadi apabila terdapat akumulasi bilirubin dalam darah, sehingga kulit dan sklera bayi tampak kekuningan. Pada sebagian besar bayi, ikterus akan ditemukan dalam minggu pertama kehidupannya. Bayi menghasilkan bilirubin yang relatif lebih tinggi dari pada orang dewasa yang terus menerus memproduksi bilirubin, dan biasanya bayi baru lahir yang cukup tinggi, 2 sampai 3 kali lipat dari orang dewasa (Stokowski, 2011). Angka kejadian ikterus terdapat $60 \%$ bayi cukup bulan dan $80 \%$ bayi prematur (Windariza, 2017).

Data di Amerika Serikat terdapat 65\% bayi mengalami ikterus. Penelitian yang dilakukan Chime dkk di Nigeria tahun 2011 didapatkan prevalensi ikterus neonatorum 33\% dengan 21\% laki-laki dan 12\% perempuan (Kusumah, 2017). Data ikterus neonatorum di Indonesia yang diperoleh dari beberapa rumah sakit pendidikan, diantaranya RSCM dengan prevalensi ikterus pada bayi baru lahir sebesar $58 \%$ untuk kadar bilirubin $\geq 5 \mathrm{mg} / \mathrm{dL}$ dan $29,3 \%$ untuk kadar bilirubin $\geq 12$ $\mathrm{mg} / \mathrm{dL}$ pada minggu pertama kehidupan (Windariza, 2017).

Kondisi hiperbilirubinemia yang berkepanjangan dapat mengakibatkan kernikterus yaitu keadaan kerusakan pada otak akibat perlengketan kadar bilirubin pada otak (Kumar, dkk, 2010). Tanda dan gejalanya adalah bayi tidak mau minum atau menghisap, ketegangan otot, leher kaku, penurunan kesadaran dan akhirnya kejang sehingga dibutuhkan penanganan yang cepat dan tepat. Salah satu penatalaksanaan yang dapat dilakukan adalah pemberian fototerapi (Kumar, dkk, 2010).

Fototerapi merupakan modalitas terapi dengan menggunakan sinar yang dapat digunakan untuk pengobatan hiperbilirubinemia pada neonates. Azlin (2011) mengungkapkan bahwa fototerapi saat ini merupakan standar pengobatan untuk bayi dengan hiperbilirubinemia neonatal efeknya secara bertahap dapat menurunkan kadar bilirubin. Pemberian fototerapi merupakan faktor kunci kecepatan penanganan hiperbilirubinemia. Efektifitas fototerapi antara lain ditentukan oleh panjang gelombang sinar lampu, kekuatan lampu (irradiance), jarak antara lampu dengan bayi, dan luas area tubuh bayi yang terpapar sinar lampu (Stokowski, 2011).

Kemampuan fototerapi diantaranya termasuk dalam penghantar sinar melalui bola lampu flourescent, lampu quartz halogen, emisi dioda lampu, dan matres optik fiber. Keberhasilam pelaksanaan tindakan keperawatan tergantung dari efektivitas fototerapi dan minimnya komplikasi yang terjadi (Stokowski, 2011). Ada beberapa jenis fototerapi yang banyak digunakan, fototerapi terus menerus, fototerapi konvensional, fototerapi intensif, hidrasi, dan paparan sinar matahari. Rumah X Jakarta menggunakan 2 jenis fototerapi yaitu Billy Blanket dan fototerapi konvensional.

Billy Blanket adalah perangkat fototerapi portable untuk pengobatan hiperbilirubinemia. Billy Blanket adalah merek dagang dari General Electric Datex-Ohmeda, istilah sehari-hari untuk berbagai produk serupa dan istilah yang digunakan dalam profesi medis. Billy Blanket juga dikenal sebagai selimut bilirubin (Kusumah, 2017). Penelitian tentang pemakaian Billy Blanket sudah dilakukan di Amerika sejak tahun 1990 dan telah dipublikasikan $J$ Paediatr Child Health di tahun 1995. Penelitian tersebut membandingkan penggunaan fototerapi Billy Blanket dengan foto terapi konvensional pada hiperbilirubin bayi prematur. Hasil penelitian tersebut ada 24 bayi pada kelompok konvensional dan 20 pada kelompok BillyBlanket. Rata-rata durasi fototerapi, untuk pemakaian fototerapi konvensional 44 jam dan pemakaian Billy Blanket 42 jam. Pada awalnya fototerapi konvensional yang digunakan dan saat ini lebih mengarah Billy Blanket (Kusumah, 2017).

Bayi baru lahir yang mengalami hiperbilirubin di RS X Jakarta selama 6 bulan terakhir berjumlah 50 bayi, dimana bayi yang menggunakan Billy Blanket sebanyak 34 bayi dan fototerapi konvensional sebanyak 16 bayi. Hasil penelitian menunjukkan adanya perbedaan yang signifikan pada kelompok Billy Blanket saat sebelum dan sesudah intervensi dengan nilai $\mathrm{p}=0.000$ (p Value $<0.05$ ) sementara untuk kelompok fototerapi konvensional dengan nilai $\mathrm{p}=0.028$ ( $\mathrm{p}$ Value $<0.05$ ). Hal ini menunjukkan bahwa antara kelompok fototerapi konvensional dan Billy Blanket didapati perbedaan yang bermakna terhadap penurunan kadar bilirubin lebih cepat (Kusumah, 2017). Berdasarkan fenomena tersebut, penelitian ini bertujuan untuk mengetahui gambaran karakteristik neonatus yang 
menggunakan Billy Blanket dengan perubahan kadar bilirubin RS X Jakarta.

\section{Metode Penelitian}

Desain penelitian yang digunakan dalam penelitian ini adalah desain deskriptif analitik dengan metode kuantitatif. Populasi adalah keseluruhan obyek yang menjadi pusat perhatian penelitian (Jones \& Bartlett, 2012). Populasi dalam penelitian ini terdiri dari neonatus yang mengalami hiperbilirubinemia dengan pemakaian Billy Blanket yang dirawat di Rumah Sakit X Jakarta yaitu sebanyak 60 responden pada Bulan Januari sampai Juni 2018. Sampel merupakan bagian populasi yang akan diteliti atau sebagian jumlah dari populasi (Polit \& Beck, 2012). Teknik pengambilan sampel yang digunakan adalah total sampling (keseluruhan populasi yang berjumlah 60 orang). Sampel dalam penelitian ini adalah keseluruhan pasien dengan hiperbilirubinemia yang menggunakan fototerapi Billy Blanket. Analisis data dengan menggunakan analisis data univariat untuk mengetahui gambaran distribusi frekuensi dari karakteristik dan penurunan kadar bilirubin neonatus yang mengunakan Billy Blanket.

\section{Hasil dan Pembahasan Karakteristik Responden}

Berdasarkan karakteristik jenis kelamin responden sebagian besar $(51,7 \%)$ berjenis kelamin laki-laki. Hasil penelitian Madiastuti dan Chalada (2016) menyebutkan bahwa bayi dengan jenis kelamin perempuan 1,6 kali lebih berpotensi untuk tidak mengalami hiperbilirubinemia dibandingkan dengan bayi berjenis kelamin lakilaki. Pada bayi laki-laki, hiperbilirubin lebih cepat diproduksi dibandingkan pada bayi perempuan. Hal ini disebabkan karena bayi laki-laki memiliki protein pada hepar yang berperan dalam uptake bilirubin ke sel-sel hepar (Hanafi dalam Madiastuti \& Chalada, 2016).

Berdasarkan karakteristik berat badan lahir bayi $100 \%$ bayi memiliki berat badan lahir normal ( $\geq 2500$ gram). Berat Badan Lahir Rendah (BBLR) merupakan penyebab tersering terjadinya hiperbilirubinemia di wilayah Asia Tenggara. Hiperbilirubenemia merupakan suatu kegawatan yang sering terjadi pada bayi baru lahir, sebanyak $20-25 \%$ terjadi pada bayi cukup bulan dan $80 \%$ terjadi pada bayi prematur dengan berat badan lahir rendah. Ditinjau dari peningkatan konsentrasi bilirubin serum, pada bayi yang lahir cukup bulan terjadi peningkatan konsentrasi bilirubin serum sebanyak $10 \mathrm{mg} \%$ atau lebih setiap 24 jam. Pada bayi yang tidak cukup bulan terjadi peningkatan konsentrasi bilirubin serum sebanyak $12,5 \mathrm{mg} \%$ atau lebih setiap 24 jam (Hidayat dalam Chalada, 2016).

Hasil penelitian menunjukan bahwa 73,3\% responden dalam penelitian ini dilahirkan dengan usia kehamilan cukup bulan ( $\geq 37$ minggu). Hafizah dan Imelda (2013) menyebutkan bahwa semakin rendah masa gestasi dan semakin kecil bayi yang dilahirkan, maka akan semakin tinggi morbiditas dan mortalitasnya. Pada bayi yang dilahirkan kurang bulan dengan berat badan rendah biasanya akan menimbulkan beberapa permasalahan seperti sindroma gangguan pernapasan, hiperbilirubinemia, daya hisap yang lemah dan sebagainya sehingga bayi harus dilakukan pemantauan yang intensif.

Hasil penelitian menunjukan bahwa sebagian besar responden berusia 2 hari (40\%). Pada ikterus fisiologis, awitan terjadi pada 2 jam pertama kehidupan setelah lahir. Kadar bilirubin akan mulai menurun pada usia 3 sampai hari kehidupan setelah lahir dan akan terus menurun sampai usia 7 hari setelah kelahiran (Mathindas, Wilar \& Wahani, 2013). Proses tersebut tentunya sangat dipengaruhi oleh usia gestasi dan berat badan lahir bayi.

Tabel 1. Karakteristik Responden

\begin{tabular}{lcc}
\hline \multirow{2}{*}{ Variabel } & \multicolumn{2}{c}{ Distribusi Frekuensi } \\
\cline { 2 - 3 } & $\mathbf{n}$ & $\mathbf{\%}$ \\
\hline Jenis kelamin balita & & \\
Perempuan & 31 & 51,7 \\
Laki-laki & 29 & 48,3 \\
\hline Umur kehamilan & & \\
2 37 Minggu & 44 & 73,3 \\
< 37 Minggu & 16 & 26,7 \\
\hline Usia Bayi & & \\
2 Hari & 24 & 40 \\
3 Hari & 21 & 35 \\
4 Hari & 6 & 10 \\
5 Hari & 6 & 10 \\
6 Hari & 3 & 5 \\
\hline Total & $\mathbf{6 0}$ & $\mathbf{1 0 0}$ \\
\hline
\end{tabular}

Sumber data: data sekunder, 2018 
Faletehan Health Journal, 6 (3) (2019) 106-110 www. journal.Ippm-stikesfa.ac.id/ojs/index.php/FHJ ISSN 2088-673X | e-ISSN 2597-8667

Ikterus fisiologis terjadi pada bayi baru lahir dengan kadar bilirubin tak terkonjugasi pada minggu pertama $>2 \mathrm{mg} / \mathrm{dl}$. Pada bayi cukup bulan yang diberi susu formula, kadar bilirubin akan mencapai puncaknya 6-8 mg/dl pada hari ke-3 kehidupan dan kemudian akan menurun lambat sebesar $1 \mathrm{mg} / \mathrm{dl}$ selama 1 sampai 2 minggu. Pada bayi cukup bulan yang mendapatkan ASI, kadar bilirubin puncak akan mencapai kadar yang lebih tinggi (7-14 $\mathrm{mg} / \mathrm{dl}$ ) dan penurunan terjadi lebih lambat bisa terjadi selama 2-4 minggu bahkan sampai 6 minggu masa kehidupan (Mathindas, Wilar \& Wahani, 2013).

Berdasarkan tabel 2 diketahui bahwa rata-rata pengukuran kadar bilirubin awal responden adalah sebesar 15,118 g/dl (St. Deviasi=0,824) dengan kadar bilirubin terendah 13,9 g/dl dan kadar tertinggi $16,9 \mathrm{~g} / \mathrm{dl}$. Rata-rata pengukuran kadar bilirubin responden setelah 24 jam menggunakan Billy Blanket adalah sebesar 13,662 g/dl (St. Deviasi=0,873) dengan kadar bilirubin terendah $11,9 \mathrm{~g} / \mathrm{dl}$ dan kadar tertinggi $16 \mathrm{~g} / \mathrm{dl}$. Rata-rata pengukuran kadar bilirubin responden setelah 48 jam menggunakan Billy Blanket adalah sebesar $12,115 \mathrm{~g} / \mathrm{dl}$ (St. Deviasi=0,593) dengan kadar bilirubin terendah $11 \mathrm{~g} / \mathrm{dl}$ dan kadar tertinggi 13 $\mathrm{g} / \mathrm{dl}$. Rata-rata pengukuran kadar bilirubin responden setelah 72 jam menggunakan Billy Blanket adalah sebesar 9,912 g/dl (St. Deviasi= 1,185 ) dengan kadar bilirubin terendah $6,7 \mathrm{~g} / \mathrm{dl}$ dan kadar tertinggi $11,3 \mathrm{~g} / \mathrm{dl}$.

Billy Blanket adalah perangkat fototerapi portabel untuk pengobatan penyakit kuning neonatal (hiperbilirubinemia). Ini merupakan sebuah alternatif untuk pengobatan rawat inap di rumah sakit untuk manajemen tingkat bilirubin tinggi pada bayi baru lahir. Billy Blanket didesain untuk pemakian yang efisien dan aman khusus perawatan pada bayi yang baru lahir dengan konsentrasi serum bilirubin tinggi. Ini melibatkan paparan dari bayi yang baru lahir ke sumber cahaya ultraviolet (bili-light) di rumah untuk jangka waktu yang ditentukan (Kusumah, 2017). Hasil penelitian ini didukung oleh Penelitian yang dilakukan oleh Kusumah (2017) tentang "Efektivitas Pemakaian Fototerapi Billy Blanket dan Fototerapi Konvensional terhadap Penurunan Kadar Bilirubin" Hasil penelitian menunjukkan adanya perbedaan yang signifikan pada kelompok Billy Blanket saat sebelum dan sesudah intervensi dengan nilai $\mathrm{p}=0.000$ sementara untuk kelompok fototerapi konvensional dengan nilai $\mathrm{p}=0.028$. Hal ini menunjukkan bahwa antara kelompok fototerapi konvensional dan Billy Blanket terdapat perbedaan yang bermakna terhadap penurunan kadar bilirubin lebih cepat.

Berdasarkan tabel 3 diketahui bahwa rata-rata penurunan kadar bilirubin responden setelah 24 jam menggunakan Billy Blanket adalah sebesar $1,465 \mathrm{~g} / \mathrm{dl}$ (St. Deviasi=0,984) dengan penurunan kadar bilirubin terendah $0 \mathrm{~g} / \mathrm{dl}$ dan penurunan kadar bilirubin tertinggi 3,7 g/dl. Rata-rata penurunan kadar bilirubin responden setelah 48 jam menggunakan Billy Blanket adalah sebesar $1,547 \mathrm{~g} / \mathrm{dl}$ (St. Deviasi=1,0) dengan penurunan kadar bilirubin terendah $0 \mathrm{~g} / \mathrm{dl}$ dan penurunan kadar tertinggi $4 \mathrm{~g} / \mathrm{dl}$. Rata-rata penurunan kadar bilirubin responden setelah 72 jam menggunakan Billy Blanket adalah sebesar 2,203 g/dl (St. Deviasi=1,11) dengan penurunan kadar bilirubin terendah $0,7 \mathrm{~g} / \mathrm{dl}$ dan penurunan kadar tertinggi 5,0 $\mathrm{g} / \mathrm{dl}$. Hasil penelitian ini sejalan dengan penelitian Dewi, Kardana, dan Suarta (2016) yang menyatakan bahwa BBL dengan usia gestasi 35$<37$ minggu mengalami gestasi penurunan kadar bilirubin total sebanyak $2,25 \pm 0,69 \mathrm{mg} / \mathrm{dL} / 24 \mathrm{jam}$, sedangkan pada bayi dengan usia gestasi 37-42 minggu mengalami penurunan kadar bilirubin total sebanyak 2,6 $\pm 0,86 \mathrm{mg} / \mathrm{dL} / 24 \mathrm{jam}$.

Tabel 2. Rata-Rata Kadar Bilirubin pada Bayi Hiperbilirubinemia Menggunakan Billy Blanket dengan

\begin{tabular}{cccc}
\hline Pengukuran & Mean & $\begin{array}{c}\text { St. } \\
\text { Deviasi }\end{array}$ & Min-Max \\
\hline Awal & 15,118 & 0,824 & $13,9-16,9$ \\
24 Jam & 13,662 & 0,873 & $11,9-16$ \\
48 Jam & 12,115 & 0,593 & $11-13$ \\
72 Jam & 9,912 & 1,185 & $6,7-11,3$ \\
\hline
\end{tabular}

Tabel 3. Rata-Rata Penurunan Kadar Bilirubin Pada Bayi Hiper-bilirubinemia Dengan Menggunakan Billy Blanket

\begin{tabular}{cccc}
\hline Pengukuran & Mean & $\begin{array}{c}\text { St. } \\
\text { Deviasi }\end{array}$ & Min-Max \\
\hline 24 Jam & 1,465 & 0,984 & $0-3,7$ \\
48 Jam & 1,547 & 1,0 & $0-4$ \\
72 Jam & 2,203 & 1,11 & $0,7-5$ \\
\hline
\end{tabular}


Fototerapi mengubah bilirubin di kapiler superfisial dan jaringan interstitial dengan reaksi fotokimia dan fotooksidasi menjadi isomer secara cepat, yang larut dalam air dan dapat diekskresikan melalui hepar tanpa proses konjugasi sehingga mudah diekskresi tanpa menjadi toksik (Kosim, Soetandio, \& Sakundarno, 2008). Rohsiswatmo dan Amandito (2018) mengungkapkan bahwa panjang gelombang paling efektif yang digunakan untuk fototerapi adalah antara (460-490) nm dari spektrum biru. Untuk memaksimalkan iradiasi dan efektivitas terapi, jarak sumber cahaya dan bayi harus dalam jarak 10-15 cm. Dampak fototerapi dengan menggunakan Billy Blanket juga dipengaruhi oleh kadar bilirubin awal responden. Dampak fototerapi akan semakin meningkat jika kadar bilirubin di kulit semakin tinggi. Selain itu, semakin dekat paparan sinar fototerapi dengan bayi, semakin efektif untuk menurunkan kadar bilirubin (Dewi, Kardana, \& Suarta, 2016).

Terjadinya perbedaan rata-rata penurunan kadar bilirubin total pada responden disebabkan karena banyak hal, salah satunya adalah sumber nutrisi bayi (hidrasi). Pemberian ASI durasi paparan fototerapi terhadap bayi menjadi lebih singkat. Hal ini disebabkan karena pemberian ASI yang adekuat akan meningkatkan motalitas usus dan menyebabkan bakteri mudah masuk ke usus (Rahmah, Yetty, Besral, 2012). Bakteri tersebut mampu mengubah bilirubin direk menjadi urobilin yang tidak dapat diabsorbsi kembali sehingga kadar bilirubin akan turun (Martiza, dalam Apriyulan \& Dwihestie, 2017).

\section{Simpulan}

Penggunaan Billy Blanket dapat menurunkan kadar bilirubin secara bertahap dari hari ke hari. Lamanya durasi fototerapi ditentukan oleh nilai total serum biliribun saat pertamakali dilakukan fototerapi dan keadekuatan hidrasi yang diberikan pada bayi tersebut.

\section{Referensi}

Apriyulan, E.M., \& Dwihestie, L.K. (2017). Hubungan Frekuensi Pemberian ASI dengan Derajat Ikterus Neonatorum Fisiologis Di RSU PKU Muhammadiyah I Yogyakarta. Naskah Publikasi.

Azlin, E. (2011). Efektifitas Fototerapi Ganda dan Fototerapi Tunggal dengan Tirai Pemantul Sinar pada Neonatus yang Mengalami Jaundice.
Dewi, S., A. K., Kardana, I. M., \& Suarta, K. (2016). Efektifitas Fototerapi Terhadap Penurunan Kadar Bilirubin Total pada Hiperbilirubinemia Neonatal di RSUP Sanglah. Sari Pediatri, Vol 18, No 2

Hafizah \& Imelda. (2013). Faktor-Faktor yang Berhubungan dengan Kejadian Hiperbilirubinemia di Ruang NICU RSUD Dr. Zainoel Abidin Banda Aceh.

Kosim, M.S, Soetandio, R., \& Sakundarno, M. (2008). Dampak Lama Fototerapi Terhadap Penurunan Kadar Bilirubin Total pada Hiperbilirubinemia Neonatal. Sari Pediatri, 10(3), 201-206

Kumar, Abbas, Fausto, \& Aster. (2010). Pathologic Basis of Disease. Robins and Cotran.

Kusumah, P. D. (2017). Efektivitas Pemakaian Fototerapi Billy Blanket dan Fototerapi Konvensional terhadap Penurunan Kadar Bilirubin pada Bayi Hiperbilirubinemia. Hiperbilirubinemia, fotote.rapi konvensional, Billy Blanket.

Madiastuti, M., \& Chalada, S. (2016). FaktorFaktor yang Berhubungan dengan Kejadian Neonatus Hiperbilirubin di RSB Pasutri Bogor.

Mathindas, S., Wilar, R., \& Wahani, A. (2013). Hiperbilirubinemia pada neonatus. Jurnal Biomedik, Volume 5, nomor 1, Suplemen.

Polit, \& Beck, P. (2012). Essentia;1 of Nursing Research : apparaising evidence for nursing practice. Lippinocot Williams \& Wilkins.

Rahmah, Yetti, K., \& Besral. (2012). Pemberian ASI Efektif Mempersingkat Durasi Pemberian Fototerapi. Jurnal Keperawatan Indonesia, Volume 15, no. 1

Rohsiswatmo, R., \& Amandito, R. (2018). Hiperbilirubinemia pada neonatus $>35$ Minggu di Indonesia: Pemeriksaan dan Tatalaksana Terkini. Sari Pediatri; 20 (2): 115-122

Stokowski. (2011). Fundamentals of Phototherapy for Neonatal Jaundice. Advances in Neonatal Care.

Windariza, W. (2017). Besar Resiko antara BBLR Kurang Bulan dengan Cukup Bulan terhadap Ikterus Neonatorum di RSPKU Muhammadiyah Tegal. Ikterus Neonatorum, Bayi Kurang Bulan, Bayi Cukup Bulan, Bayi $B B L R$. 